\title{
The Endurance Ability Analysis Persikopa Football Players of Pariaman City
}

\author{
Ridho Bahtra ${ }^{1 *}$, Moch. Asmawi ${ }^{2}$, and Widiastuti ${ }^{3}$ \\ ${ }^{1}$ Sports Science Faculty, Universitas Negeri Padang, Padang, Indonesia \\ ${ }^{2,3}$ Postgraduate, Universitas Negeri Jakarta, Jakarta, Indonesia \\ *Corresponding author. Email: ridhobahtra@fik.unp.ac.id
}

\begin{abstract}
This study aims to determine the endurance ability Persikopa football players of Pariaman City. The study was conducted at the AMS Pauh football field in Pariaman City. The method used in this research is descriptive method. Sampling in this study through total sampling technique. The sample was 25 Persikopa football players 18-year-old (U-18) in Pariaman City. The data collection method used in this study was by testing and measuring. The test instrument used was the Yo-Yo Intermitten Recovery Test (Yo-Yo IR Test). Data analysis technique used was frequency distribution. From the result of data analysis, it shows that the average $\mathrm{VO}_{2} \mathrm{Max}$ capacity of players is 43.88, hence it can be concluded that the endurance ability of Persikopa players U-18 in Pariaman City is still low.
\end{abstract}

Keywords: Endurance, Young Players, Football

\section{INTRODUCTION}

The idea of football game is to put the ball (score a goal) into the opponent's goal as much as possible and defend the goal from the opponent. Based on the idea of this football game, the football game is getting more and more interesting. Each team with their respective coaches is competing to be the best. In addition to winning as a form of achievement, the team is also required to present attractive and entertaining football.

Achievement improvement is supported by various factors such as physical condition, technique, tactic, mentality, coach, facility and infrastructure, athlete status, nutrition, and others. Performance in the soccer complex and include technical elements, tactical, psychological, and physical [3]. In football the performance of a player depends on technical, tactical and physical skills, which can be achieved if the players have good components of endurance, speed, flexibility, strength and agility. [5].

Of the many elements of physical condition, one of the most important ones possessed by players is good endurance ability. In general, endurance can be interpreted as a person's ability to overcome fatigue due to physical and psychological work for a long time $[2,13]$. Endurance is the body's ability to perform physical activities with a certain intensity and within a certain period of time [11]. Furthemore, endurance is defined as the ability to work with a certain intensity in a long period of time, without excessive fatigue [8]. Based on this quote, it can be concluded that endurance is the body's ability to overcome fatigue after doing physical activity.

In football, endurance becomes the main foundation for players. The time of the match for $2 \times 45$ minutes, even in certain situations plus $2 \times 15$ minutes, will drain the players' energy. Movement in football is not only done with the ball, but also without the ball (with and without the ball). Players who control the ball will do dribbling, passing to his friends, or penetration into the opponent's defense area. Meanwhile, the players without the ball move to offend the opponent, or move with high mobility to support their teammate who is dribbling the ball. Thus, endurance is needed in order that the players' movement remains consistent throughout the game.

The general purpose of endurance in football is to maintain an intensive effort until the end of the match, working with good aerobic and anaerobic qualities. [14]. Football is a sport with high intensity activities, such as sprinting, high-intensity running, turns and jumping [10]. In an article of explained Football is a primarily endurance-based sport, interspersed with repeated highintensity efforts [1].

Football Association Pariaman City (Persikopa) is a place for young football players in Pariaman City. Every year the Persikopa club regularly participates in competitions held by the Indonesian Football Association (PSSI). Some of these competitions include League 3, U-17 Soeratin Cup, and U-15 Soeratin Cup. These competitions are official competitions and the 
permanent agenda of PSSI, starting at the local level, regional level, up to the national level.

One of the competitions regularly followed by Persikopa is the U-17 Soeratin Cup. Throughout its participation in this competition, Persikopa has never achieved maximum achievement or champion. In the last three years Persikopa cannot do much in this competition. According to the data from the Persikopa match results from the past three years, statistically the percentage of Persikopa wins is very small compared to the defeats. The percentage of Persikopa wins is only $15 \%$ from 13 matches, $8 \%$ draw and $77 \%$ defeat.

From this match data, a study needs to be conducted to identify the problems. Therefore, one of the indicators highlighted is the ability of physical conditions, especially the endurance ability of Persikopa players. When the coach already has accurate data, the training program prepared will be in accordance with the needs of the team, so that the problems can be fixed.

\section{METHOD}

This study is a descriptive research which aims to express something as it is. The study was conducted at the AMS Pauh football field in Pariaman City. The sample in this study is the Persikopa U-18 as many as 25 people. Data collection technique used is tests. The test instrument used in this study was the Yo-Yo Intermitten Recovery Test (Yo-Yo IR test) [3]. After the data were collected, the data were then compiled, and then data processing was done by descriptive statistical analysis by using frequency tabulation technique or percentage technique.

\section{RESULT}

To get data on the endurance ability Persikopa players of Pariaman City, tests were done by using the Yo-Yo Intermitten Recovery Test (Yo-Yo IR test). From the results of endurance ability tests conducted on 25 samples, it was obtained the Highest Score (maximum) 46.48, the Lowest Score (minimum) 40.43, the Average (Mean) 43.88, and the standard deviation (SD) 1.85 . The frequency distribution table can be seen in the following table 1 :

Table 1. Frequency Distribution of Endurance Ability $\left(\mathrm{VO}_{2} \mathrm{Max}\right)$ Persikopa Players of Pariaman City

\begin{tabular}{|c|c|c|c|}
\hline No & Interval Class & $\mathrm{Fa}$ & $\mathrm{Fr}$ \\
\hline 1 & $40.43-41.48$ & 2 & 8.00 \\
\hline 2 & $41.49-42.90$ & 8 & 32.00 \\
\hline 3 & $42.91-44.32$ & 5 & 20.00 \\
\hline 4 & $44.43-45.74$ & 4 & 16.00 \\
\hline 5 & $45.76-47.17$ & 6 & 24.00 \\
\hline \multicolumn{2}{|r|}{ Total } & 25 & $100 \%$ \\
\hline
\end{tabular}

Based on the data in the table above, it can be concluded that the endurance ability ( $\mathrm{VO}_{2} \mathrm{Max}$ capacity) Persikopa football players of Pariaman City is on the average level of $41.49-42.90$. These results explain that the player's endurance ability is still relatively low. In football, the average requirement for endurance (VO2Max) players is at the level of 60-65. For a clearer picture of the endurance ability of Pariaman City Persikopa players, it can be seen in the figure below:

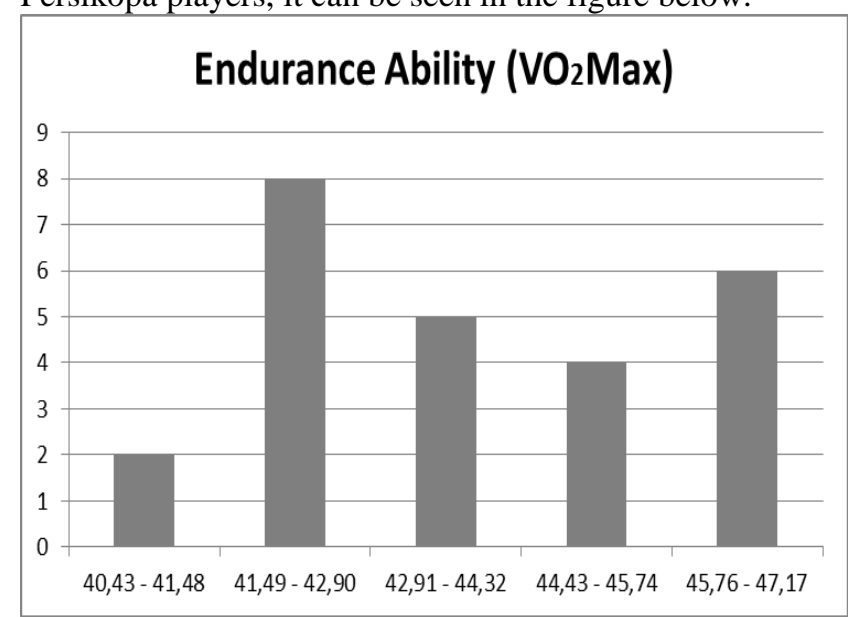

Figure 1. Endurance Ability ( $\left.\mathrm{VO}_{2} \mathrm{Max}\right)$ Persikopa Players of Pariaman City

\section{DISCUSSION}

From the results of data analysis that has been done, it shows that the average $\mathrm{VO}_{2} \mathrm{Max}$ capacity of players is 44.41 . It can be concluded that the endurance ability of Persikopa Players U-18 is still low. This suggests that the player's endurance ability is still low compared to the $\mathrm{VO}_{2} \max$ capacity requirement of football players at level 60 - 65. In fact, endurance ability is one of the most important elements possessed by football players.

Based on available data, it is necessary to analyze the cause of the low endurance ability of Persikopa players, things that make the players' endurance ability are at a low level. Theoretically, there are several factors which affect it, both internal and external factors. Internal factors such as the motivation of players in undergoing the training process, the anatomical and physiological characteristics of the player, and external factors such as the training material provided, the training methods used, and several other factors. All of those factors should be examined properly so that the problem of the player's endurance ability can be overcome.

Apart from all the problems, the thing which should be done to improve the endurance ability is to undergo the training process well. Good endurance 
ability will help players in making decisions in undergoing the match. The level of endurance can predict the quality of a player's performance especially at the end of each match where the player puts the last effort to win the match [4]. Aerobic fitness is an important component in team sports to help maintain a high level appearance throughout the match, aid rapid recovery and help maintain the quality of technical and tactical decision making [9]. This indicates that the level of endurance ability is crucial for players in making decisions.

To improve endurance ability, continuous and systematic training is needed, with a method which suits the player's condition. This means that the training is performed according to the characteristics of the sport and the player. Physical training, especially endurance, can be trained using balls. Use small field games and technical training drills to forge endurance. This is what is called football conditioning (forging the condition of players through football itself) [11]. There are many training methods that a professional football team can use to improve the physical condition of its players, general exercise (for example, continuous, intermittent and repetitive sprinting) and specific exercise (for example, small game, soccer specific and positionspecific exercise with ball) [12].

Specific training will provide an update in the endurance training of football players. With specific training, the players can feel the atmosphere of the match since they do not only run but also carry out actions with the ball. The motivation of the players is expected to be increased to complete the entire set of exercises given by the coach since the players are not only provided with monotonous training material, but varied forms of training. The impact is certainly on the players themselves, in which there will be an increase in the endurance ability.

The goal of endurance training with specific football was stated by Dr. Schlumberger that explained He sees the objectives of soccer-specific endurance training as follows: 1) Ability to perform optimally for 90 to 120 minutes, 2) optimal performance for each individual high-intensity explosive action, 3) during the game the optimal capacity for repetition of highintensity burst performance, 4) maintaining the same intensity over a long period of time, 5) Reaching higher intensity in the same time period, 6) Good cardiovascular capacity function, 7) Good muscle metabolism function [7].

Moreover, thus endurance athlete's can be obtained by replacing some training methods with high intensity training. It is interesting not only for elite endurance athletes but also for active recreation individuals who want to optimize performance [6].
In developing the endurance of a football player, it would be better given in accordance with the existing stages. This is done in order that the player develops according to his age and provides training load according to his age as well. The development of a football player can be divided into four phases:1) Fundamental phase (5 to 11 Years), 2) Training to train (11 to 14 Years), 3) Training to compete (14 to 20 Years), 4) Training to win (20 Years and Older) [12]. This theory explains that for the age of 18 years, it is the right phase to develop the endurance ability of football players.

\section{CONCLUSION}

From the results of data analysis and discussion it can be concluded that the ability endurance of Persikopa football players U-18 is still low. To improve the endurance ability of players, it is necessary to do systematic and continuous training which in accordance with the principles of physical condition training, and by using training methods which are appropriate with the characteristics of players and sports.

\section{REFERENCES}

[1] Badin, O. O., Smith, M. R., Conte, D., \& Coutts, A. J. (2016). Mental fatigue impairs technical performance in small-sided football games. International Journal of Sports Physiology and Performance. https://doi.org/http://dx.doi.org/10.1123/ijspp.2015-0710

[2] Bafirman. (2008). Pembentukan Kondisi Fisik. Malang: Wineka Media.

[3] Bangsbo, J., \& Mohr, M. (2015). Fitness Testing in Football: Fitness Training in Football II. Bangsbosport.

[4] Cobar, A. G. C., \& Madrigal, N. (2016). Effect of endurance training with weighted vest on the 3000 meter running time of high school boys. Journal of Physical Education and Sport, 16(2), 301-310. https://doi.org/10.7752/jpes.2016.02048

[5] Fadhil Farhan, A., Justine, M., \& Kamil Mahammed, S. (2013). Effect of training program on physical performance in junior male Malaysian football players. Journal of Physical Education and Sport, 13(2), 238243. https://doi.org/10.7752/jpes.2013.02039

[6] Gunnarsson, T. P., Christensen, P. M., Thomassen, M., Nielsen, L. R., \& Bangsbo, J. (2013). Effect of intensified training on muscle ion kinetics, fatigue development, and repeated short-term performance in endurance-trained cyclists. American Journal of Physiology-Regulatory, Integrative and Comparative Physiology, 305(7), R811-R821. https://doi.org/10.1152/ajpregu.00467.2012

[7] Hyballa, P., Dost, H., \& Poel;, H.-D. te. (2016). Football Functional Fitness Training. Meyer \& Meyer Sport.

[8] Irawadi, H. (2010). Kondisi Fisik dan Pengukurannya. Padang: Fakultas Ilmu Keolahragaan Universitas Negeri Padang.

[9] Pichardo, A. W., Oliver, J. L., Harrison, C. B., Maulder, 
P. S., \& Lloyd, R. S. (2018). Integrating models of longterm athletic development to maximize the physical development of youth. $0(0), \quad 1-11$. https://doi.org/10.1177/1747954118785503

[10] Radziminski, L., Rompa, P., Barnat, W., Dargiewicz, R., \& Jastrzebski, Z. (2013). A Comparison of the Physiological and Technical Effects of High-Intensity Running and Small-Sided Games in Young Football Players. 8(3), 455-466.

[11] Scheunemann, T. S. (2012). Kurikulum \& Pedoman Dasar Sepakbola Indonesia: Untuk Usia Dini (U5-U12), Usia Muda (U13-U20) \& Senior (I. S. Bert Pentury, Emral Abus, ed.). Jakarta.

[12] Strudwick, T. (2016). Football Science. https://doi.org/LCC GV943 .S66 2016 | DDC 796.334-$\mathrm{dc} 23$ LC record available at http://lccn.loc.gov/2015042253

[13] Syafruddin. (2011). Ilmu Kepelatihan Olahraga (1st ed.; T. E. U. Press, ed.). Padang: UNP Press Padang.

[14] Taylor, J. J. (2016). Youth Football. www.FIFA.com, 257. 